\title{
Effects of Service Quality, Customer Trust and Corporate Image on Customer Satisfaction and Loyalty: An Assessment of Travel Agencies Customer in South Sumatra Indonesia
}

\author{
Heri Setiawan ${ }^{1}$, A.Jalaluddin Sayuti ${ }^{2}$ \\ ${ }^{1,2}$ (Business Administration Department, State Polytechnic of Sriwijaya, Indonesia)
}

\begin{abstract}
This study aims to determine the determinant of customer satisfaction and their implications for consumer loyalty. The method used in this study is a survey method. The population in this study is that consumers who have use the services of tour and travel companies in South Sumatra. This research use of purposive sampling technique. To meet the minimum requirements path analysis then taken sample of 200 respondents to the provisions of the election to travel agencies customers in South Sumatra. The results showed that there are influences between the variables of service quality, trust and corporate image on consumer satisfaction. There is influence between service quality and customer satisfaction. There is influence between trust and customer satisfaction. There are influences between service quality, trust and customer satisfaction on consumer loyalty. There is influence between service quality and customer loyalty. There is no influence between trusts on customer loyalty. There is influence between customer satisfaction and customer loyalty.
\end{abstract}

Keywords: Service Quality, Trust, Costumer Satisfaction, Loyalty, Travel Agent

\section{Introduction}

Tourism is an important part of economy and the fastest sector to develop in the world and able to induce the important part of other economies (Osman and Sentosa, 2013). Travel service and tourism industry is leading global economy in 2012 above manufacturing, retail, financial service and communication industry. This industry has grown with the total contribution of PDB of $3 \%$ and increased the job absorbtion rate. More than $10 \%$ of all new jobs created in 2012 came from this industry. One of the main factors that determine the competitiveness and business success, both in the service sector and sub-sectors of tourism and travel, in particular is the quality of service. Improved quality of service and high quality service delivery, as part of the responsibilities of the tourism business, can better produce and maintain long-term relationships with stakeholders, among which the most important is the customer. At the same time, to be sustainable, businesses in various sectors should give great attention to create, maintain and increase customer loyalty, as well as managing customer relationships in adequately long-term. This is done in order to ensure consistent future and predict revenue. In addition, the company favored by the customer should have the orientation of sustainability to gain consumer loyalty (Mandhachitara and Poolthong, 2011).

Berry et al., (1988) stated that service quality is an important market differentiator and an instrument of strong competitiveness and should be owned by all the service organization. There are several reasons which service quality should be considered an important issue. First, the quality of higher service yield higher customer satisfaction (Johns et al., 2004), then service quality and customer satisfaction affects the level of customer loyalty (Cristobal et al., 2007). Second, customer loyalty and long-term implicitly, will be compared to short-term customers, where facts revealed that consumers who make repeat purchases, have a greater tendency to purchase additional services, will use the communication through word of mouth. Service quality is considered the standard by which to judge the effectiveness of an institution recreational service, including tourism sector (Godbey, 1997), and therefore the quality of the services involved with tourism plays an important role in the delivery process (Wyllie, 2000). Quality of care is affected customers imagery that has an effect on the process of the expected quality of perception of quality (Prabaharan et al., 2008). Happiness is directly related to satisfaction, and happiness as a whole is strongly associated with satisfaction in the travel sector (Glatzer, 2000). The majority of tourists have experience with purpose, and their perception is influenced by a comparison between the facilities, attractions, and service standards (Law, 1995).

Travel agency has an important role in the tourism industry as a tourist event organizer. In this case, travelers who use the services of travel agents feel that the party that responsible for their travel while they are in a tourist area is travel agents. One important focus must be considered by the business travel agency is giving good service and security to the tourists. In Palembang, there are currently 198 businesses listed in ASITA of South Sumatra and engaged in tourism travel. Any business engaged in tourism off travel holiday packages services to consumers both outside and within the country. Package tours organized by travel agencies registered in ASITA of South Sumatra contains a minimum of information about the package name of travel, 
duration of travel, routes and travel activities (itinerary), the price of travel packages in rupiah currency, modes of transport, type of accommodation, and travel insurance. It is the obligation of travel agency to give detail information to the tourists. Moreover, protection is given in form of insurance, as an obligation that travel agency should met. Therefore, to be able to provide a satisfactory service, every business must understand the character and culture of travelers who use the services.

Over the last decade, researchers have been giving great attention to service quality, customer trust, corporate image, customer satisfaction and customer loyalty. Although there are many studies on the service quality, customer trust, corporate image, satisfaction and loyalty in several tourism and travel industry such as airlines and hotel industry, but research that examines the service quality customer trust, corporate image, customer satisfaction and customer loyalty in Southern Sumatra in particular the city of Palembang is still very rare.

\section{Service Quality}

\section{Literature Review}

Traditionally, the quality of service has been conceptualized as the difference between customer expectations regarding the services to be received and perceptions of services received (Grönroos, 2001). In previous studies, the quality of service relates to the extent to which the service is able to meet the needs or expectations of customers (Dotchin \& Oakland, 1994). It is also conceptualized as a whole consumer impression relative to the inferiority or superiority of service (Zeithaml, Berry, and Parasuraman, 1990). After a comprehensive review of service quality study, Asubonteng, McCleary, and Swan (1996) concluded that the number of dimensions of service quality varies in different industries. Kettinger and Lee (1994) identified four dimensions in the study of information systems (IS) quality, which do not have a tangible dimension. Variable service quality consists of five main dimensions, namely: reliability, which is an ability to provide the promised services accurately. Responsiveness is a policy to assist and provide fast service to customers. Assurance is knowledge, friendliness of employees, as well as the ability to spontaneously carry out tasks, which can ensure good performance, so that engenders trust and confidence of customers. Empathy is a concern about the individual that given to customers and strive to understand the customer's wishes. Tangibility is the appearance and capabilities of physical infrastructure that is reliable, as well as the state of the environment, such as a concrete demonstration of the service provided by a service provider (Parasuraman et al., 1991: 422). For this study the researchers have employed five dimensions of service quality proposed by Parasuraman et al., (1988).

\section{Trust}

Trust is defined as the willingness of consumers to rely on the company based on the consumer confidence (Moorman et al, 1993). In business, confidence is seen as one of the most relevant stable predecessors and collaborative relationship. Researchers have established trust, which is essential for building and maintaining long-term relationships (Rousseau, et al., 1998; Singh \& Sirdeshmukh, 2000). Morgan and Hunter (1994) states that trust will only exists when one party has confidence in an exchange of partner's reliability and integrity. Meanwhile Moorman et al., (1993) defines trust as a willingness to rely on an exchange partner in whom one has confidence. According to Lau and Lee (1999), if one party believes the other party, it will ultimately lead to positive behavioral intentions toward the second party. Anderson and Narus (1990) conclude that if one party believes that the actions of the other party will bring positive results for the first party, the trust can be developed. Furthermore, Doney \& Cannon (1997) adds that the person concerned must also have the ability to continue to meet its obligations to customers in the cost-benefit relationship; thus, customers not only predict positive results but also believe that these positive results will continue in the future.

\section{Corporate Image}

The company's image is defined as the overall impression in the minds of customers as a result of the accumulation of feelings, ideas, attitudes and experience with organizations that are stored in memory that may turn out to be positive/negative meaning, taken to reconstruct the image and recalled when the organization's name is heard or brought to mind of someone (Bravo et al., 2009). Corporate image is defined by Nguyen and Leblanc (2001: 228) as something that is associated with physical attributes and behavior of firms such as company name, architecture, products and services, quality impression communicated by consumers who have used the products and services company. The company's image is the result of a communication process in which organizations create and deploy specific message that is the purpose of their strategic form of mission, vision, purpose and identity that reflects the core values that they cherish (Bravo et al., 2009). This is consistent with the opinion of Keller (1993) related to brand image. Therefore, the company's image may be considered as a kind of brand image in which the brand name refers to the organization as a whole compared to the products / services of the company. 


\section{Customer Satisfaction}

Customer satisfaction is a well-known concept and established in many fields such as marketing, consumer research, economy psychology, economic welfare and economy. The general interpretation of customer satisfaction is the feeling that is generated from an evaluation process of what have been received, expected, including purchasing decision as well as needs and wants related to that decision (Armstrong and Kotler, 2009). Bitner and Zeithaml (2003) state that satisfaction is a customer evaluation of products or services in terms of their ability in fulfilling customer's needs and wants. According to Boselie et al., (2002), satisfaction is positive and affective achieved through the evaluation of many aspects.

\section{Customer Loyalty}

As identified by researchers, customer loyalty is a construct comprising both customer attitudes and behavior. Components of the customer's attitude is an idea such as: intention to repurchase or buy additional products or services from the same company, willingness to recommend the company to others, demonstration of commitment to the company by exhibiting resistance to switch to another competitor (Cronin \& Taylor, 1992; Narayandas, 1996), and willingness to pay a premium price (Zeithaml, Berry, and Parasuraman, 1996). On the other hand, the behavior of customer loyalty represent the actual of repurchasing of products or services that include more purchase of different products or services from the same company, recommend the company to others, and reflects the probability of long-term option for brands (Feick, Lee, \& Lee, 2001). Customer loyalty can be concluded as the behavior that is associated with products or services or to the company. Pearson (1996) has defined customer loyalty as the mindset of customers who hold a favorable attitude toward the company, is committed to buy back the company's products / services, and recommend a product / service to others. We have used the definition of Pearson (1996) for this study.

\section{Conceptual Framework}

Based on the literature review, an analysis has been used to draw conclusions about the causal relationship between the variables studied. The objectives of the study are: examining the relationship between service quality, customer trust, corporate image, customer satisfaction and customer loyalty The conceptual framework and hypothesis of this research can be can be proposed and described below.

H1 : Service quality significantly affects consumer satisfaction

$\mathrm{H} 2$ : Trust significantly affects customer satisfaction

$\mathrm{H} 3$ : Corporate image significantly affects customer satisfaction

$\mathrm{H} 4$ : Service quality significantly affects customer loyalty

H5 : Corporate image significantly affects customer loyalty

H6 : Consumer satisfaction significantly affects consumer loyalty

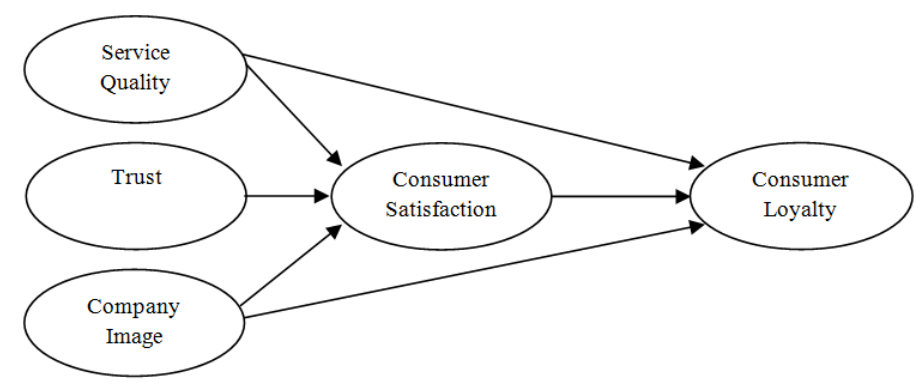

Figure 1: Conceptual Framework

\section{Research Design}

\section{Methodology}

In this study uses a quantitative approach, where a lot of research with quantitative approach is required to use numbers, ranging from data collection, data interpretation, and discussion of the results of the analysis. This research is causality research, which shows the causal relationships between the independent variable on the dependent variable in addition to measuring the magnitude of the relationship between these variables through hypothesis testing. In this study, independent variables are service quality, trust and corporate image while the dependent variables are customer satisfaction and loyalty. Service quality variable defines as the degree of distance between reality and expectations of customers with the services obtained. Trust variable defines as experience, feeling, emotion, or user behavior that occurs when they feel that someone is reliable in acting for their best interests. Corporate image defines as physical attributes and behavior of firms such as company name, architecture, products and services, quality impression communicated by customers who have used the products and services company. Customer satisfaction defines as feelings and attitudes of customers 
after using the products and services. Customer loyalty defines as a deep commitment to repurchase and subscribe for a preferred product consistently in the future. All of indicators in this study are measured by using 5-point Likert scale such as: $1=$ strongly disagree, $2=$ disagree, $3=$ average agree, $4=$ agree, $5=$ strongly agree.

\section{Population and Samples}

In this study uses a quantitative approach, where a lot of research with quantitative approach is required to use numbers, ranging from data collection, data interpretation, and discussion of the results of the analysis. This research is causal research, which shows the causal relationships between the independent variable on the dependent variable in addition to measuring the magnitude of the relationship between variables through hypothesis testing. The method used in this study is a survey method. The population in this study is customers that use the services of a travel agencies in South Sumatra. The type of sampling is purposive sampling based on certain considerations, where the sample is selected with the terms deemed to have essential features that are relevant to the research. Determination of the sample size of the population, based on the minimum sample size suggested by the analysis tools used. The guidelines are 5-10 the number of parameters to be estimated (Augusty, 2005). The research sample is 200 respondents that are chosen by specific criteria on the customers of travel agencies in South Sumatra.

\section{Data Analysis}

Validity test is used to indicate the extent to which a question is able to reveal something that will be measured. The validity test ensures that each question will be classifiable on variables that have been set (construct validity). If a question is able to reveal something that will be measured by questionnaires then the data is valid, where the value for the variance extracted should be bigger than 0.50. Reliability test is used to measure whether a respondent answers consistently. When respondents are consistent in answering the questions in the questionnaire, the data is reliable. High reliability test results provide assurance that the indicators questionnaire consistent with the measurement. The level of reliability that is generally accepted is bigger than 0.60 (Nunnaly, 1978).

\section{Results And Discussion}

The customers of travel agencies in South Sumatra that are used as respondents are amounted up to 200 people. The demographic characteristics of these respondents are divided into gender, age and occasion. Table 1 represents the frequency and percentage of respondents based on the characteristics.

Table 1: Respondents Characteristics

\begin{tabular}{|l|l|l|l|l|}
\hline No & Characteristics & Description & Frequency & Percentage \\
\hline 1 & Gender & Male & 65 & 32,2 \\
& & Female & 135 & 67,8 \\
& \multirow{2}{*}{ Age } & $18-25$ years old & 176 & 88,0 \\
& & $26-33$ years old & 13 & 6,5 \\
3 & \multirow{3}{*}{ Occasion } & $>33$ years old & 11 & 5,5 \\
& & Civil servants & 52 & 26,0 \\
& & Entrepreneurs & 25 & 12,5 \\
& & Private Employees & 20 & 10,0 \\
\hline
\end{tabular}

The respondents of this study consist of 65 males (32.2\%) and 135 females (67.8\%). Based on the age category, there are 176 customers with age of 18-25 years old (88\%) and 13 people with age of 26-33 years old $(6.5 \%)$ while only 11 people with age of older than 33 years old (5.5\%). $26 \%$ (52 people) of the respondents are working as civil servants, $12.5 \%$ ( 25 people) as entrepreneurs, $10 \%$ (20 people) as private employees and $51,5 \%$ (103 people) are categorized as others. This study used the Statistical Package for Service Solution (SPSS) as a tool to analyze data. Validity test is done by using Pearson Correlation, where $\mathrm{r}$ table is 0.1391 .

Table 2: Reliability Analysis

\begin{tabular}{|l|l|l|l|}
\hline Variable & N of Item & Item Deleted & Alpha \\
\hline Service Quality & 6 & - & 0.877 \\
Customer Trust & 6 & - & 0.859 \\
Corporate Image & 6 & - & 0.843 \\
Customer Satisfaction & 5 & - & 0.845 \\
\hline Customer Loyalty & 6 & - & 0.832 \\
\hline
\end{tabular}

Reliability test is performed to determine the extent to which the level of data reliability for the study. A variable is said to be reliable if the respondent's answer to the question is consistent or stable over time. A 
variable is said to be reliable if the value of r-value is larger than Cronbach Alpha of 0.60 (Nunnaly, 1978). The statistical analysis to be performed was coefficient Cronbach's alpha to measure the internal reliability analyses to examine various scales. Reliabilities of these scales were as follows: service quality is 0.877 , customer trust is 0.859 , corporate image is 0.843 , customer satisfaction is 0.845 and customer loyalty is 0.832 . Based on the testing for the independent variables and the dependent variable, on each item, it shows that the r-value is bigger than 0.1391 indicating that all the data in the test are valid.

Table 3: Correlation Analysis

\begin{tabular}{|l|l|l|l|l|l|}
\hline Variables & Service Quality & Customer Trust & Corporate Image & Customer Satisfaction & Customer Loyalty \\
\hline Service Quality & 1.000 & $.682^{* *}$ & $.650^{* *}$ & $.670^{* *}$ & $.712^{* *}$ \\
\hline Customer Trust & $.682^{* *}$ & 1.000 & $.620^{* *}$ & $.641^{* *}$ & $.625^{* *}$ \\
\hline Corporate Image & $.650^{* *}$ & $.620^{* *}$ & 1.000 & $.672^{* *}$ & $.678^{* *}$ \\
\hline Customer Satisfaction & $.670^{* *}$ & $.641^{* *}$ & $.672^{* *}$ & 1.000 & $.806^{* *}$ \\
\hline Customer Loyalty & $.712^{* *}$ & $.625^{* *}$ & $.678^{* *}$ & $.806^{* *}$ & 1.000 \\
\hline
\end{tabular}

Correlation is significant at the 0,01 level (2-tailed)

Evidence in table (3) showed that there was a significant positive relationship between service quality and customer trust $(\mathrm{r}=0.682, \mathrm{P}<0.1)$ and between service quality and corporate image $(\mathrm{r}=0.650, \mathrm{P}<0.1)$, and between service quality and customer satisfaction $(\mathrm{r}=0.670, \mathrm{P}<0.1)$, and between service quality and customer loyalty $(\mathrm{r}=0.712, \mathrm{P}<0.1)$. Evidence in table ( 3 ) showed that there was a significant positive relationship between customer trust and corporate image $(\mathrm{r}=0.620, \mathrm{P}<0.1)$ and between customer trust and customer satisfaction $(\mathrm{r}=0.641, \mathrm{P}<0.1)$, and between customer trust and customer loyalty $(\mathrm{r}=0.625, \mathrm{P}<0.1)$. Evidence in table (3) showed that there was a significant positive relationship between corporate image and customer satisfaction $(\mathrm{r}=0.672, \mathrm{P}<0.1)$ and between corporate image and customer loyalty $(\mathrm{r}=0.678, \mathrm{P}<0.1)$, and between customer satisfaction and customer loyalty $(\mathrm{r}=0.806, \mathrm{P}<0.1)$. It can be explained that there is a very strong positive relationship between service quality, customer trust, corporate image, customer satisfaction and customer loyalty. In other words, the higher services quality provided by the company to the customer, a high level of consumer trust and a good image of customers about corporate will increase customer satisfaction and loyalty. Thus H1, H2, H3, H4, H5, H6 and H7 were supported.

Table 4: Regression Analysis

\begin{tabular}{|l|l|l|c|c|}
\hline Independent Variable & Dependent Variable & B & t- value \\
\hline Service Quality & Customer satisfaction & 0.309 & 6.366 & Sig. \\
Customer Trust & Customer satisfaction & 0.302 & 5.067 & 0.000 \\
Corporate Image & Customer satisfaction & 0.305 & 5.238 & 0.000 \\
Service Quality & Customer Loyalty & 0.222 & 4.876 & 0.000 \\
Customer Trust & Customer Loyalty & 0.259 & 4.980 & 0.000 \\
Corporate Image & Customer Loyalty & 0.236 & 4.925 & 0.000 \\
Customer Satisfaction & Customer Loyalty & 0.631 & 0.333 \\
Constant $=6,344$ & & & \\
R Square $=0,512$ & & & \\
Adj R Square $=0,507$ & & & \\
F Stat $=3.183$ & & & \\
Sig F $=0,0000$ & & & \\
\hline
\end{tabular}

The first hypothesis states that service quality significantly affects customer satisfaction. The result indicate that service quality has positive and significant affect on customer satisfaction with $\beta=0,309$, t-value $=6,366$, and sig.0,000. This indicates that there is an association between service quality and customer satisfaction amounted up to 0.309 or $30.9 \%$. This results support the previous study by Sureshchandar et al., (2003) and Ribbink et al., (2004) that identify the strong relationship between service quality and customer satisfaction. Hu \& Huang (2011) in their study on customers air cargo terminal in Taiwan stated that service quality has exhibited the most significant influence on customer satisfaction. Akbar \& Parvez (2009) in their study on 304 customers of a major private telecommunication company operating in Bangladesh found that service quality has strong influence and significantly and positively related to customer satisfaction. Hossain \& Leo (2008) in their study revealed that service quality is a strong antecedent and significantly related to customer satisfaction in their study of banking industry in Qatar. Chen \& Lee (2008) in their study on 261 non vessel owners and shippers in Taiwan found that service quality has a positive influence with customer satisfaction in International Logistic provider. Gounaris et al., (2003) in their study on 240 online shoppers in Greece retailing industry revealed that service quality has significant impact and positive relationship with customer satisfaction

Furthermore, The second hypothesis states that customer trust significantly affects customer satisfaction. The result indicate that customer trust has positive and significant affect on customer satisfaction with $\beta=0,302$, t-value $=5,067$, and sig. 0,000 . The magnitude of effect of service quality on customer 
satisfaction is 0.302 or $30.2 \%$. This result is support the studies by Kandampully \& Hu (2007) and Chattananon (2007) that explain corporate image affects customer satisfaction. Gul ( 2014) in his study shows that there is significant and positive influence customer trust on customer satisfaction.

The third hypothesis states that coporate image significantly affects customer satisfaction. The result indicate that coporate image has significant and positive affect on customer satisfaction with $\beta=0,305$, $t$-value $=5,238$, sig. 0,000 and the magnitude of influence of 30.5\%. This results support the previous studied by ElSalam et al., (2013); Andreassen \& Lindestad (1998); Zins (2001) that identify the strong relationship between coporate image and customer satisfaction. The results also support the studies by Hu \& Huang (2011) that explain corporate image has shown significant positive influence on customer satisfaction. Ali et al., (2015) in their study on customer in Pakistan telecommunication industry revealed that corporate image significantly enhancing the customer satisfaction. It can concluded that corporate image results from an evaluation process, which originates from thoughts, feelings, and previous consumption experience in relation to a business entity, turning consumers' memories into spiritual impression (Yuille \& Catchpole, 1977).

The fourth hypothesis states that service quality significantly affects customer loyalty. The result indicate that service quality has positive and significant affect on customer loyalty with $\beta=0,222$, $\mathrm{t}$-value $=$ 4,876 , sig. 0,000 and magnitude of influence of $22.2 \%$. The results are consistent with the previous studies by Quan (2010) states that have revealed the same relationship between service quality and loyalty in China banking industry. Qiang \& Mei, 2010; Rahnama, et al., 2012; Jamal, \& Kriyaki. 2007 found in their study that service quality has positive and significant impact on customer loyalty. Lee (2010) conducted a study on mobile phone users in South Korea showed that service quality also have significant and positive influence on customer loyalty. Mokhtar, et al., (2011) in their study on students about Malaysian telecommunication industry also revealed the positive relationship between service quality and the customer loyalty. Aydin et al., (2005) in their study found there is positive relationship between service quality and loyalty among Turkish mobile phone users. Chen \& Lee (2008) in their study revealed that service quality has strong and significant relationship with customer loyalty in their International Logistic provider industry. Liang (2008) study on 308 hotel guests of hotel industry in United Stated revealed that service quail has a positive influence and significant relationship with customer loyalty. Clottey et al., (2008) in their study of 972 retail customers of United States retail industry have found the strong statistical evidence that service quality has a great influence where it positively and significantly correlated with customer loyalty. Jamal \& Anatassiadou (2007) in their study found the relationship between service quality and customer satisfaction in banking industry in Greece, they also study the relationship between service quality and customer loyalty and they found their study that service quality has a strong impact and positively and significantly related to customer loyalty in banking industry in Greece.

The fifth hypothesis states that customer trust significantly affects customer loyalty. The result indicate that customer trust has positive and significant affect on customer loyalty with $\beta=0.259, \mathrm{t}=4.980$, and sig. 0,000 . This means that there is an influence between trust on customer loyalty. The magnitude of influence of customer trust on customer loyalty is 0.259 or $25.9 \%$. When one believes others in interpersonal relationships, he or she would rely himself or herself on the other party and will further bring its intention to maintain a relationship that is represented in the form of buying loyalty. The results are consistent with the previous studies by Upamannyu et al., (2015) that explain there is strong cause and effect relationship between customer trust and customer loyalty. Sarwar et al., (2012) in their study on Cellular Service Operators in Pakistani context also revealed the Customer Loyalty is greatly affected by Customer Trust in the Pakistani cellular companies because Pakistani cellular companies try to deliver that service level which they have declared. Sarwar et al., (2012) stated when organizations provide and fulfil their core values and promises appropriately then they gain the trust of customers. While when they add augmented values with core values they create a bridge to convert customers from the level of trust to loyalty.

The sixth hypothesis states that corporate image significantly affects customer loyalty. The result indicate that corporate image has positive and significant affect on customer loyalty with $\beta=0.236$, $t$-value $=$ 4.925, and sig. 0,000. This means that there is influence between the variables of corporate image and customer loyalty. The magnitude of influence of corporate image on Customer loyalty is 0.236 or $23.6 \%$. The results support the findings of previous research conducted by Kandampully \& Hu (2007); Nguyen \& Leblanc (2001), Agyei \& Kilika (2013), Boohene \& Agyepong (2011), Nukpezah \& Nyumuyo (2010), Loverlock \& Writz (2007), and Ad-El-Salam \& Shawky (2013) which states that corporate image has a positive relationship with customer loyalty. Agyei \& Kilika (2014) in their study on the mobile telecommunication market in Kenya stated that Corporate Image positively correlated with customer loyalty. It is clear that the better the image of the company, the higher customer loyalty. Corporate image is important to study because of the potential effect on customer loyalty.

The last hypothesis states that customer satisfaction significantly affects customer loyalty. The result indicate that customer satisfaction has significant and positive effect on customer loyalty with $\beta=0.631$, $\mathrm{t}$ value $=10.333$, and sig. 0,000. This means that there is an association between customer satisfaction and 
customer loyalty. The magnitude of the influence of cutomer satisfaction on customer loyalty is 0.631 or $63.1 \%$. The results support the findings of previous research done by Cronin \& Taylor (2000), Hart \& Johnson (1999) that suggest customer satisfaction has significant affect on customer loyalty. Faullant et al., (2008) in their study on 6172 ski-resort customers in Australia have found that customer satisfaction is positively and significantly correlated to customer loyalty. Pantouvakis \& Lymperopoulos (2008) have done the study on 388 ferry passengers in Greece and revealed that customer satisfaction has great impact on customer loyalty and positively and significantly correlated with customer loyalty. Akbar \& Parvez (2009) in their study on 302 Telecommunication customers in Bangladesh have found that customer satisfaction is significantly and positively related to customer. Hume \& Mort (2010) conducted a study on 250 performing arts members and audience and have found that customer satisfaction very much has impact on customer loyalty and positively and significantly related. Chen \& Lee (2008) in their study on 261 non Vessel Owners and shippers in Taiwan"s International Logistic Provider industry has revealed that customer satisfaction is very critical to customer loyalty and both are positively and significant correlated. The same result found by Liang (2008) in her study on 308 Hotel guests in United States where she found that customer satisfaction is the determining factor and positively and significant correlated to customer loyalty.

\section{Conclusion}

Based on the research findings all of hypotheses are supported. The result of the analysis show that service quality has positive and significant affect on customer satisfaction. Customer trust has positive and significant affect on customer satisfaction. Coporate image has significant and positive affect on customer satisfaction. Then, service quality has positive and significant affect on customer loyalty. Furthermore, customer trust has positive and significant affect on customer loyalty. Corporate image has positive and significant affect customer loyalty. Customer satisfaction has significant and positive effect on customer loyalty. These findings indicate that the quality of service, consumer trust and corporate image plays an important role in improving customer satisfaction and ultimately will make consumers become loyal to use the services of a travel agency. Travel agency in South Sumatra should pay more attention to create good service quality, to build customers' trust, make strong image of their companies, and give satisfied with their services and can make customer loyal.

The results of this study contribute to the development of services marketing studies and indicate that the service quality, customer trust and the corporate image is not only suitable to be applied in the context of hotel, restaurants and large scale service industry, but can be applied to small and medium scale of travel agency. Based on the results of this study, travel agency can optimize customer relationships by considering the variables that affect customer satisfaction and loyalty. Service quality, customer trust and corporate image will be important in maintaining the value of the relationship between business travel agency customers. Result of analysis indicate that customer satisfaction is influenced by service quality, customer trust and corporate image. Service quality, customer trust and corporate image also affects customer loyalty. The study findings indicate that customer satisfaction and loyalty will affect the sustainability of business travel agency in South Sumatra.

This study can provide insights for further research in service marketing area and help travel agency to employ the implementation of the role of service quality, customer trust and corporate image as a main driver of consumer's satisfaction and loyalty. The findings of this study have several limitations. First, the data is collected only from the customer's of travel agency in South Sumatra; so that the findings cannot be generalized to all existing customers in Indonesia. Second, this study used cross-sectional data to determine causality, it is suggested that for further research, a longitudinal approach should be used so that the result would be more appropriate. Finally, further study might also use other variables such as the perception of price, customer perceived value, commitment and switching cost to measure its impact on customer loyalty.

\section{References}

[1] Aaker, D. A. 2004 : Leveraging the Corporate Brand. California Management Review, 46 (3): 6-18.

[2] Abd-El-Salam, E.M, Shawky, A.Y \& Nahas, El, T. 2013. The Impact of Corporate Image and Reputation on Service Quality, Customer Satisfaction and Customer Loyalty: Testing the Mediating Role. Case Analysis in An International Service Company. The Business \& Management Review, 3 (2): 177-196.

[3] Agyei, P. M., \& Kilika, J. M. 2013. Relationship between service quality and customer loyalty in the Kenyan telecommunication service industry. European Journal of Business and Management, 5(23): 26-36.

[4] Agyei, Paul Mensah \& Kilika, James M. 2014. Relationship between Corporate Image and Customer Loyalty in the Mobile Telecommunication Market in Kenya. Management Studies. 2 (5): 299-308

[5] Akbar, Mohammad Muzahid \& Parvez, Noorjahan. 2009. Impact of Service Quality, Trust, and Customer Satisfaction on Customer Loyalty, ABAC Journal, 29 (1): 24-38.

[6] Ali, Rizwan., Leifu, Gao., Rafiq, Muhammad Yasir \& Hassan, Mudassar. 2015. Role Of Perceived Value, Customer Expectation, Corporate Image And Perceived Service Quality on The Customer Satisfaction, The Journal of Applied Business Research, 31 (4): 1425- 1436.

[7] Anderson, J. C. \& Narus, J. A. 1990. A Model of Distributor Firm and Manufacturer Firm Working Partnerships. Journal of Marketing, 54 (1): 42-58.

[8] Anderson, E.W. \& Sullivan, M.W. 1993. The Antecedents and Consequences of Customer Satisfaction for Firms. Marketing science, 1993. 12 (2): 125-143. 
[9] Andreassen, T. W., \& Lindestad, B. 1998. Customer loyalty and complex services: the impact of corporate image on quality, customer satisfaction and loyalty for customers with varying degrees of service expertise. International Journal of service Industry management, 9(1): 7-23.

[10] Armstrong, Gary \& Kotler, Philip. 2009. Marketing An Introduction, Ninth Edition. New Jersey: Prentice Hall

[11] Asubonteng, P., McCleary, K. J. \& Swan, J. E. 1996. Servqual Revisited: A Critical Review of Service Quality. Journal of Services Marketing, 10 (6): 62-81.

[12] Augusty, T. Ferdinand. 2005. Structural Equation Model in Management Research. Semarang, UNDIP Publising.

[13] Aydin, S., Ozer, G., \& Arasil, O. 2005. Customer Loyalty and the Effect of Switching Costs as a Moderator Variable A Case in the Turkish Mobile Phone Market. Marketing Intelligence \& Planning, 23 (1): 89-103.

[14] Bansal, H. S. \& Taylor, S. F. 1999. Beyond Service Quality and Customer Satisfaction: Investigating Additional Antecedents of Service Provider Switching Intentions. Proceedings of the 1999 Academy of Marketing Science (AMS) Annual Conference. 75-82.

[15] Berry, L.L., Parasuraman, A. \& Zeithaml, V.A., 1988. The service - quality puzzle. Business Horizons, 31(5): 35-43.

[16] Bitner, M. J. \& Zeithaml, V. A. 2003. Service Marketing ( $3^{\text {rd }}$ ed.), Tata McGraw Hill, New Delhi.

[17] Bitner, M. J. 1990. Evaluating Service Encounters: the Effect of Physical Surroundings and Employee Responses, Journal of Marketing, 54 (4): 69-82.

[18] Bolton, R.N. \& Drew, J.H. 1991. A Multistage Model of Customers' Assessments of Service Quality and Value', Journal of Consumer Research, 17 (4): 375-384.

[19] Boeselie, P., Hesselink, M. \& Wiele, T.V. 2002. Empirical Evidence for the Relationship between Customer Satisfaction and Business Performance. Managing Service Quality, 12 (3): 184-193.

[20] Boohene, R., \& Agyapong, G. K. Q. 2011. Analysis of the antecedents of customer loyalty of telecommunication industry in Ghana: The case of vodafone (Ghana). International Business Research, 4(1): 229-240.

[21] Bravo, Rafael., Montaner, Teresa., \& Pina, José M. 2009. The Role of Bank Image for Customers versus Non-Customers, International Journal of Bank Marketing, 27(4): 315-334.

[22] Cameran, M., Moizer, P., \& Pettinicchio, A. 2010. Customer Satisfaction, Corporate Image, and Service Quality in Professional Services. The Service Industries Journal, 30(3): 421-435.

[23] Chaudhuri, A., \& Holbrook, M. B. 2001. The Chain of Effects from Brand Trust and Brand Affect to Brand Performance: the Role of Brand Loyalty. The Journal of Marketing, 81-93.

[24] Chattananon, Apisit., Meredith, Lawley., Trimetsoontorn, Jirasek., Supparerkchaisakul, Numchai \& Leelayouthayothin, Lackana. 2007. Building Corporate Image Through Societal Marketing Programs, Society and Business Review 2 (3): $230-253$.

[25] Chen, C. H., \& Lee, H. Y. 2008. Empirical Analysis of the Customer Loyalty Problem in the International Logistics Market. WSEAS Transaction on Business Economics, 4(5): 113-123.

[26] Clottey, T. A., \& Collier, D. A. 2008. Drivers Of Customer Loyalty In A Retail Store Environment. Journal of Service Science, 1(1): 35-47.

[27] Cristobal, E., Flavián, C., \& Guinalíu, M. 2007. Perceived E-Service Quality (PeSQ): Measurement Validation and Effects on Customer Satisfaction and Website Loyalty". Managing Service Quality, 17 (3): 317-340.

[28] Cronin, J. \& Taylor, A. 1992. Measuring Service Quality: A Reexamination and Extension. Journal of Marketing, 56 (3): $55-58$.

[29] Dabholkar, P.C., Shepherd, D., \& Thorpe, D.I. 2000. A Comprehensive Framework for Service Quality: An Investigation of Critical Conceptual and Measurement Issues Through a Longitudinal Study. Journal of Retailing 76 (2): 139-73.

[30] Doney, P. M. \& Cannon, J. P. 1997. An Examination of the Nature of Trust in Buyer-Seller Relationships. Journal of Marketing, 61 (4): 35-51.

[31] Dotchin, J. A. \& Oakland, J. S. 1994. Total Quality Management in Services Part 2 : Service Quality". International Journal of Quality \& Reliability Management, 11 (3): 27-42.

[32] Faullant, R., Matzler, K., \& Fuller, J. 2008. The impact of satisfaction and image on loyalty: the case of Alpine ski resorts. Managing Service Quality, 18(2): 163-178.

[33] Feick, L. \& Lee, J. 2001. The Impact of Switching Cost on the Customer Satisfaction-Loyalty link; Mobile Phone Service in France. Journal of Service Marketing, 15 (1): 35-48.

[34] Fornell, C. 1992. A national customer satisfaction barometer: the Swedish experience. the Journal of Marketing, 6-21.

[35] Glatzer, W. 2000. Happiness: classic theory in the light of current research. Journal of Happiness Studies, 1(4): 501-511.

[36] Godbey, G. 1997. Leisure and leisure services in the 21st century. State College, PA: Venture Publishing.

[37] Grönroos, C. 2001. The Perceived Service Quality Concept a Mistake? Managing Service Quality, 11 (3): $150-152$

[38] Grönroos, C. 1994. From Marketing Mix to Relationship Marketing: Towards a Paradigm Shift in Marketing. Management Decision, 32(2): 4-20.

[39] Gounaris, S. P., Stathakopoulos, V. \& Athanassopoulos, A. D. 2003. Antecedents to perceived service quality: An exploratory study in the banking industry. The International Journal of Bank Marketing. 21(4/5): 168-190.

[40] Guenzi, P., Johnson, M. D., \& Castaldo, S. 2009. A comprehensive model of customer trust in two retail stores. Journal of Service Management, 20 (3): 290-316.

[41] Hart, C. W. \& Johnson, M. D. 1999. Growing the Trust Relationship. Marketing Management, 14: 8-19.

[42] Hossain, M., \& Leo, S. 2008. Customer perception on service quality in retail banking in Middle East: the case of Qatar. International Journal of Islamic and Middle Eastern Finance and Management, 2(4): 338-350.

[43] Hu, Kai. Chieh \& Huang, Mei Chieh. 2011. Effects of Service Quality, Innovation and Corporate Image on Customer's Satisfaction and Loyalty of Air Cargo Terminal. International Journal of Operations Research, 8 (4): 36-47.

[44] Hume, M., \& Mort, G.S. 2010. The consequence of appraisal emotion, service quality, perceived value and customer satisfaction on repurchase intent in the performing arts. Journal of Services Marketing, 24(2): 170-182.

[45] Jamal, Ahmad \& Anatassadou, Kriyaki. 2007. Investigating the effects of service quality dimensions and expertise on loyalty, European Journal of Marketing, 43(3): 398-420.

[46] Johns, N., Avci, T. \& Karatepe, O.M., 2004. Measuring service quality of travel agents: evidence from Northern Cyprus. The Service Industries Journal, 24(3): 82-100.

[47] Islam, M. S. 2010. The Analysis of Customer Loyalty in Bangladeshi Mobile Phone Industry. World Journal of Management, 2 (2): $130-145$.

[48] Kandampully, J. \& Hu, H.H. 2007. Do Hoteliers Need to Manage Image to Retain Loyal Customers?, International Journal of Contemporary Hospitality Management, 19 (6): 435-443.

[49] Keller, K. L. 1993. Conceptualizing, Measuring, and Managing Customer-based Brand Equity. Journal of Marketing, 57 (1): 1-22.

[50] Kettinger, W. J. \& Lee, C. C. 1994. Perceived Service Quality and User Satisfaction with the Information Services Functions. Decision Sciences, 25 (5/6): 737-766. 
[51] Kotler, P. 2000. Marketing Management: Analysis, Planning, Implementation and Control $9^{\text {th }}$ ed. Prentice-Hall, Upper Saddle River, N.J.

[52] Kotler, Philip, 2007, Manajemen Pemasaran, Jilid 2, Edisi 12, Jakarta, PT Indeks.

[53] Kotler, P. \& Keller, K. 2009. Marketing Management. New Jersey: Person Education.

[54] Laws, E. 1995. Tourist Destination Management: Issues, Analysis, and Policies. New York: Routledge.

[55] Lau, G. \& Lee, S. 1999. Customers' Trust in a Brand and Link to Brand Loyalty. Journal of Market Focused Management, 4: 34170.

[56] Lee, Hyung Seok. 2010. Factors Influencing Customer Loyalty of Mobile Phone Service: Empirical Evidence from Koreans, Journal of Internet Banking and Commerce, 15(2): 1-14.

[57] Liang, D. 2008. The Determining Factors of Customer Loyalty for Luxury Hotels in US. The Journal of International Management Studies, 3(2): 167-175.

[58] Loverlock, C., \& Writz, J. 2007. Services marketing: People, technology, strategy (6th ed.). New Jersey, Upper Saddle River: Pearson Prentice Hall.

[59] Mandhachitara, R \& Poolthong, Y.2011. A model of customer loyalty and corporate social responsibility. Journal of Service Marketing.25(2): 122-133.

[60] Mandhachitara, Rujirutana \& Poolthong, Yaowalak. 2009. "Customer Expectation of CSR, Perceived Service Quality and Brand Effect in Thai Retail Banking," International Journal of Bank Marketing, 27(6): 408-427.

[61] Mascarenhas, O. A., Kesavan, R., \& Bernacchi, M. 2006. Lasting customer loyalty: A total customer experience approach. Journal of Consumer Marketing, 23(7): 397-405.

[62] Mokhtar, Sany Sanuri Mohd., Maiyaki, Ahmed Audu \& Noor, Norzaini bt Mohd. 2011. The Relationship Between Service Quality and Satisfaction on Customer Loyalty in Malaysian Mobile Communication Industry", School of Doctoral Studies (European Union) Journal, 6(3): 32-38.

[63] Morgan, R. M. \& Hunt, S. D. 1994. The Commitment Trust Theory of Relationship Marketing”. Journal of Marketing, 58 (7): 2038.

[64] Mowen, J.C \& Minor. M. 2002. Customer Behavior, Jakarta, Erlangga.

[65] Moorman, C., Deshpande, R. \& Zaltman, G. 1993. Factors Affecting Trust in Market Research Relationships. Journal of Marketing, 57 (1): 81-101.

[66] Narayandas, N. 1996. The Link between Customer Satisfaction and Customer Loyalty: An Empirical Investigation. Working Paper, No. 97-017, Harvard Business School, Boston, MA.

[67] Nguyen, N., \& Leblanc, G. 2001. Corporate Image and Corporate Reputation in Customers' Retention Decisions in Services. Journal of Retailing and Consumer Services, 8: 227-236.

[68] Nukpezah, D., \& Nyumuyo, C. 2010. What drives customer loyalty and profitability? Analysis of perspectives from retail customers in Ghana's banking industry. Saarbrücken: LAP Lambert Academic Publishing.

[69] Nunnally, J. C. 1978. Psychometric Theory ( $2^{\text {nd }}$ ed), McGraw Hill, NY.

[70] Oliver, R. L. 1997. Satisfaction: A behavioural perspective on the consumer. New York, NY: McGraw-Hill.

[71] Oliver, R. L. 1999. Whence Consumer Loyalty?. Journal of Marketing, 63, Special Issue, 33-44.

[72] Osman, Zahir \& Sentosa, Ilham. 2013. Influence of Suctomer Satisfaction on Servicde Quality and Trust Relationship in Malaysian Rural Tourism. Business and Management Quarterly Review, 4(2): 12-25.

[73] Pantouvakis, A., \& Lymperopoulos, K. 2008. Customer satisfaction and loyalty in the eyes of new and repeat customers. Managing Service Quality, 18(6): 623-643.

[74] Parasuraman, A., Berry, L. L., \& Zeithaml, V. A. 1991. Perceived Service Quality as A Customer-based Performance Measure: An Empirical Examination of Organisational Barriers using an Extended Service Quality Model, Human Resource Management, 30 (3): 335-364.

[75] Parasuraman, A, Zeithaml, Valarie A. \& Berry, Leonard L. 1988. Servqual: A Multiple-Item Scale for Measuring Customer Perceptions of Service Quality. Journal of Retailing. Vol 64 (1): 12-37.

[76] Peter, J. Paul \& Jerry, C Olson. 2000. Customer Behavior and Marketing Strategy. Fourth Edition. Jakarta: Erlangga.

[77] Pearson, N. 1996. Building Brands Directly: Creating Business Value from Customer Relationships. Macmillan Business, 20 (6): 68-82.

[78] Prabaharan, B., A. Arulraj, V. Rajagopal, 2008, Service Quality on Tourism : Application of Structural Equation Modelling, Conference on Tourism in India - Challenges Ahead.

[79] Qiang, Lai Sheng- \& Mei, Tang Xue. 2010. The Influence of E- service Quality on Consumer's Satisfaction and WOM, Second International Conference on Multi Media and Technology, IEEE, 172-175.

[80] Quan, Sun. 2010. Assessing the effects of e-service quality and satisfaction on internet banking loyalty in China, International Conference on E-Business and E-Government, IEEE, 93-96.

[81] Rahnama, Afshin., Alaei, Abbas., Shafaee, Javad., \& Hamdam, Hadi. 2012. Evaluating the Impact of Banking Services Quality on Customer Loyalty in Mellat Bank Ardebil Province, Journal of Basic and Applied Scientific Research, 2(3): 2498-2506

[82] Ribbink, D., Liljander, A. C. R. V. V., \& Streukens, S. 2004. Comfort Your Online Customer: Quality, Trust and Loyalty on the Internet. Managing Service Quality, 14(6): 446-456.

[83] Rizan, M. 2010. Analysis of service quality and customer satisfaction and its influence on customer loyalty. Oxford Business \& Economics Conference.

[84] Rousan, M., \& Mohamed, B. 2010. Customer Loyalty and the Impacts of Service Quality: The Case of Five Star Hotels in Jordan. International Journal of Business and Economic Sciences, 2(3): 202-208.

[85] Rousseau, D.M., Sitkin, S.B., Burt, R.S. \& Camerer, C.F. 1998. Not so Different After all: A Cross-discipline View of Trust. Academy of Management Review, 23 (3): 393-404.

[86] Sargeant, A., \& West, D.C. 2001. Customer retention - building customer loyalty. Direct \& Interactive Marketing, 177-214.

[87] Sarwar, Muhammad Zaman., Abbasi, Kashif Shafique., Pervaiz, Saleem. 2012. The Effect of Customer Trust on Customer Loyalty and Customer Retention: A Moderating Role of Cause Related Marketing. Global Journal of Management and Business Research. 12(6): 26-36.

[88] Singh, J. \& Sirdeshmukh, D. 2000. Agency and Trust Mechanisms in Customer Satisfaction and Loyalty Judgements. Journal of the Academy of Marketing Science, 28 (1): 150-67.

[89] Spreng, R.A. \& Mackoy, R.D. 1996. An Empirical Examination of a Model of Perceived Service Quality and Satisfaction, Journal of Retailing, 72: 201-214.

[90] Stan, V., Caemmerer, B., \& Cattan-Jallet, R. 2013. Customer loyalty development: The role of switching costs. Journal of Applied Business Research, 29(5): 1541-1554. 
[91] Sureshchandar, G. S., Rajendran, C. \& Anantharaman, R. N. 2003. The Relationship between Service Quality and Customer Satisfaction-a Factor Specific Approach. Journal of Service Marketing, 16 (4): 363-379.

[92] Tjiptono, Fandy. 2000. Prinsip-Prinsip TQS. Edisi Kedua. Yogyakarta: Penerbit Andi

[93] Upamannyu, K. Nischay., Gulati, Chanda., Chack, Ankita \& Kaur, Gurvinder. 2015. The Effect Of Customer Trust On Customer Loyalty And Repurchase Intention: The Moderating Influence Of Perceived CSR. International Journal of Research in IT, Management and Engineering, 5 (4): 1-31.

[94] Yee, R. W. Y., Yeung, A. C. L., \& Edwin Cheng, T. C. 2010. An empirical study of employee loyalty, service quality and firm performance in the service industry. International Journal of Production Economics, 124 (1): 109-120.

[95] Yuille, J. C., \& Catchpole, M. J. 1977. The role of imagery in models of cognition. Journal of Mental Imagery, 1: 171-80.

[96] Wyllie, R.W. 2000. Tourism and Society. State College, PA: Venture Publishing.

[97] Zeithaml, V.A., Parasuraman, A. \& Berry, L.L. 1990. Delivering Quality Service, Balancing Customer Perceptions and Expectations, The Free Press, New York, NY.

[98] Zeithaml, V. A., Berry, L. L., \& Parasuraman, A. 1996. The Behavioral Consequences of Service Quality. Journal of Marketing, 60 (2): 31-46.

[99] Zins, A. H. 2001. Relative attitudes and commitment in customer loyalty models: some experiences in the commercial airline industry. International Journal of Service Industry Management, 12(3): 269-294. 